\title{
The Importance of Bioethical Principles Involvement into the Pharmacy Study within the Academic Language Preparation
}

\author{
Viera Žufková, Darina Kližanová, Ján Kyselovič \\ Comenius University in Bratislava, Faculty of Pharmacy
}

\begin{abstract}
Bioethical issues belong to the key questions in medicine and pharmacy. The area of bioethics affects the whole pharmacists' practice, which means it also concerns their professional university education, including academic language preparation. The aim of this paper is to point out at the need to include some bioethical issues and relevant terminology into the study of pharmacy within academic language preparation. At the same time we introduce the result of our two year research (2012-2014).

The main method of research was the questionnaire spread among 115 students followed by the analysis and synthesis of students' feedback within a four semester course of Academic English Language Preparation compared to the current situation at Faculty of Pharmacy, Comenius University in Bratislava (FaPhCU). Based on the research results we have been forming a new concept of English for pharmacists. This new concept will draw the awareness to the importance of mastering English on professional level. As the bioethical principles remain the crucial part of the pharmacy profession, there is a great importance of their involvement into the academic English language study. The Code of Conduct for Pharmacy Students with its seven principles shall be a part of bioethical preparation of future pharmacists.
\end{abstract}

\section{Introduction}

These times when human life is often confronted with a culture of death that denies a respect for human person, bioethics increasingly proves its place and importance in medical and pharmaceutical practice. Institute of Medicine of the National Academies recommended that health care should be focused on the patient (coordinated, integrated), team-like (interdisciplinary), supported by evidence, supported by informatics, safer, more efficient and more effective and dedicated to continuous quality improvement [1].

Who established that pharmacists should be moved from behind of their desk and should start to provide public health care instead of still prevailing distribution of medicines [2]. Choosing the right approach regarding the inclusion of bioethical issues in the pharmaceutical profession and the relationship with patients are very important and decisive as regards the effective implementation into pharmaceutical practice. New perceptions of pharmaceutical care integrate pharmacists into a comprehensive patient's care, especially in the following tasks: prevention, access to treatment, monitoring of treatment in order to ensure its effectiveness, quality of life and the real financial cost of drugs.

\section{Literature Review}

The importance of English for Specific Purposes (ESP) has been arisen since the pharmacists started to interact with professionals, patients and customers in English. It all happened after joining the European Union. Pharmacy students and their teachers realized that studying and teaching English as a Second language (ESL) is no more sufficient. Facing this reality, English teachers at the Faculty of Pharmacy in Bratislava devoted considerable attention to the English professional language. They reflected the overall demands and formed the goals of ESP at $\mathrm{FaPhCU}$ that concentrate more on language in context than on teaching grammar and language structures and they covered topics that constantly evolve and change.

There has been a very broad discussion of differences between native English-speaking teacher and non-native English-speaking teacher. A stereotype says that a native English speaker is by nature the best person to teach English. This precondition leaves a little room for non-native English teacher. Ivan Garcia Merino from University in Northern Iowa analyzes this dispute in his paper of Native versus non-native English speaking teachers [3]. As he states from his personal experience, it seems many people from England, Spain and France believe they speak better than people from the USA, Hispanic America and Quebec, respectively. Amusingly, there are internal differences within these countries. According to Kachru, English is now 
the language of those who use it [4]. These users give it a specific feature in every region.

We would like to point out the outcome we have defined in time of being at FaPhCU and teaching English pharmaceutical terminology. Whence the specification of native and non-native English teacher exists, there are certain differences between teacher pharmacist, i.e. a master of pharmacy who teaches and is an active specialist teacher of some specific pharmaceutical field at FaPhCU, and ESP teacher non-pharmacist, i.e. a master of pedagogy in English language who teaches and is an active specialist teacher of English pharmaceutical terminology. However the differences between pharmacist teacher and ESP non-pharmacist teacher relate, influence and depend on each other.

Differences between pharmacist teacher and ESP non-pharmacist teacher are depicted in following lines:

1. Proficiency - Pharmacist teacher is a professional in pharmacy. He continuously expands his pharmaceutical terminology and searches for new information and provides research in his field. This all is the greatest advantage in teaching pharmacy. On the other hand an ESP non-pharmacist teacher has to dedicate much more effort to increase his proficiency. It takes hard study in the beginning and continuous search for new and fresh pharmaceutical topics rich in terminology. He has to master (at the basic level) all pharmacy fields in terminology and basic content.

2. Accuracy - Teaching pharmaceutical terminology means correct and accurate usage of terms that belong to the certain field of pharmacy. Teaching them in English as an ESP teacher, he has to study and communicate with pharmacist teachers from various departments and to go through lots of terminology and compare it with professional documents and research materials.

3. Confidence - Answering the question "Who is more confident in teaching pharmaceutical terminology?” is very tricky. In my opinion, there is the only difference in flexibility. Pharmacist teacher is, of course, more flexible at using the right term in the right place. ESP non-pharmacist teacher struggles with confidence of not hesitated terminology usage.

4. Terminology - There is no doubt that pharmaceutical terminology consists of the most complex terms from different fields of proficiency, i.e. chemistry, biology, botany, toxicology and others. Our students become professionals while studying at $\mathrm{FaPhCU}$ thanks to teachers pharmacists. For us, ESP non-pharmacist teachers, is the highest honour to notice like our students forget that we are "just" English teachers when they start talking and explaining new terms in pharmaceutical professional language. Automatically they assume that according to our previous lessons and performance, they can rely and speak out their mind in professional way. So throughout constant and never ending study we, ESP teachers, are gradually becoming English pharmaceutical terminology professionals.

5. Language - We definitely speak different languages. Pharmacist teacher and his students have their own language that only a professional can understand. This language culture is for us, ESP teachers, so unique that only with regular meetings and active communication with other departments at FaPhCU we become more dynamic and confident ESP teachers.

Surely there are much more differences, but those listed above give us everyday challenges we have to face and handle.

Our ESP pharmacy students are very responsible. They realize their future role and the importance of English in their study and carrier. This makes our ESP lessons more efficient and focused on active acquiring of pharmaceutical terminology, scientific texts and research materials.

The knowledge of professional terminology is a very important part of communication between pharmacists and patients or customers. It is a prerequisite for pharmacists' integration into their professional life. The future pharmacists should master specific terminology, which they can use then in various situations in a real life. At FaPhCU we have assembled terminology which can be found in the following areas:

\section{Pharmacists:}

a) Pharmacist: a specialist in pharmaceutical science working in a clinic, hospital and pharmacy worldwide. He/She may be also specialized in certain disciplines (academic pharmacist, clinical pharmacist, oncology pharmacist etc.), or work in the production and distribution of drugs.

b) Druggist: an expert in the preparation of drugs, receives prescriptions and dispenses medicines to patients with advice on the proper use of medicines, adverse effects etc.

c) Pharmaceutical representative: a special mediator between a patient and a medical care provider, ensures appropriate pharmacotherapy.

2. Pharmaceutical places:

a) Pharmacy: a place where we can get prescribed drugs, OTC drugs and other pharmaceutical products.

b) Pharmaceutical company: the place where pharmaceutical representatives work.

c) Laboratory: a place where pharmacists produce drugs and pharmaceuticals.

3. Therapy:

a) Prescription: a form confirmed by a doctor that contains appropriate medication to treat a patient.

b) Effects: main and side effects of drugs.

c) Active substances: substances contained in medicinal products.

d) Symptoms: symptoms that are signified while suffering from disease [5]. 


\section{Pharmaceutical English Terminology at FaPhCU}

As we can see, professional pharmaceutical terminology is very broad and complex. It includes terminology from many disciplines - pharmacology, toxicology, organic and inorganic chemistry, botany, physics and many others. In the process of developing the curriculum, English teachers, therefore, must take into account the programs of vocational subjects. Professional seminars in English do not overtake the themes of professional disciplines at FaPhCU.

The issues and terminology acquired in the English language seminars are parallel to those discussed in other seminars. Cross-curricular relations and cooperation thus signifies crucial importance both for the whole faculty and also for our students. At the same time they help us to determine the right direction for the development and creation of common terminology.

It is clear that pharmaceutical professional terminology is constantly evolving and therefore high demands are especially given upon the teachers. We must educate ourselves in different areas, search for information on the Internet and in specialized pharmaceutical magazines and have an overview on the development of new drugs, newly discovered active substances etc. Professional terminology is also changing with the world global research. The situation in pharmaceutical science and research brings new topics, controversial issues (vaccination, overuse of antibiotics, alternative medicine, homeopathy ...) and teachers must flexibly respond to this phenomenon.

Specialized texts in English in seminars are systematically changing, and so are constantly adapted to the professional needs of our students. In other words, this means that at the language seminars, therefore, we use materials and popular science literature, which includes specific terminology, see Appendix 1. These sources enable the study for intermediate language levels and also support self-study or work with foreign language text. Despite the fact that the professional texts do not contain specific information, i.e. chemical formulas or complicated definitions, texts that we work with however contain enough professional terminology that is appropriate for pharmacists [6].

Linked to this there is the fact that the professional level of educational texts must be regularly reviewed and amended according to the students' reactions to ensure its "suitability". We recall that a professional language is a form of professional communication, which is the opposite of a general or standard language [7]. There is a correlation between vocabulary and common language. The words are influenced by everyday language terminology, and that's the way it gets professional terminology into everyday language [8]. This provides flexible space for teachers and students who can lead the discussion on specific topics and use common language and academic terms.

\subsection{Bioethical Principles in the Pharmacy Study}

In this context we remind that the pharmacy is one of the registered health professions and carries the privileges and responsibilities. Pharmacy student must be aware that he is able to carry out the profession and full accountability. Thus, he must behave professionaly at all times and under bioethics principles. According to the Royal Pharmaceutical Society of Great Britain from the first day of study the future pharmacist must follow the Code of Conduct for Students of Pharmacy (Code of Conduct). Adherence of this Code of Conduct shall be also applied outside the university campus. The student must bear in mind that he always represents the pharmaceutical profession and his university.

This Code of Conduct was approved by the General Pharmaceutical Council [9] and British pharmaceutical students' association. In the following lines, we introduce this Code, which contains seven principles of ethics and their compliance. It helps students to understand what it means to be a pharmacist, and what principles should be followed during pharmaceutical career.

Code of Conduct consists of seven principles:

1. Make patients your first concern.

2. Use your professional judgement in the interests of patients and the public.

3. Show respect for others.

4. Encourage patients and the public to participate in decisions about their care.

5. Develop your professional knowledge and competence.

6. Be honest and trustworthy.

7. Take responsibility for your working practices.

In addition to the Code of conduct for students, the Royal Pharmaceutical Society of Great Britain identified the principles called the Code of Ethics for pharmacists and pharmacy technicians, which is intended to professional pharmacists and technicians. This Code requires that pharmacists:

- develop and use their expertise and skills for the benefit of those who seek their professional services; - maintain good professional relationships with others;

- act in a way that promotes confidence and trust in pharmacy experts [10].

For pharmaceutical profession in Slovakia there is a Code of Ethics of Pharmaceutical Industry in Slovakia [11], which was revised in February 2012. It regulates the use of prescription drugs, as well as promotional activities for health professionals and communicates with them or the relationships 
between health professionals and pharmaceutical companies and it also regulates the relationship between patients' organizations and health authorities.

The aim of the Code is not to control or standardize the provision of non-promotional medical, scientific and accurate information. The Code is not aimed to control or regulate activities directed at the general public. It applies only to products which are subjects of prescription.

\section{Methods and Methodology}

Academic English Language seminars are professionally specialised and they do not substitute a lack of foreign language training on lower levels of education. Within becoming a part of the European Union and the European labour market our graduates must be adequately linguistically prepared [12].

This academic year 2014/2015 we have been finishing the four semester cycle of Academic English language preparation and we considered it to be the best opportunity to get students'feedback and their opinion on the content and general overview of our English lessons and so complete the two year research. The number of extended questionnaires was 115. The same number was also given back, so we can state $100 \%$ return.

The asked questions were directed to identify student' requirements and suggestions which make studying pharmaceutical terminology in English more interesting and useful so they could refer to it while studying and connecting with other subjects for cross-curricular relationship and associations.

\section{Analysis and Findings}

In English seminars we speak, read texts and study pharmaceutical terminology in English. To find out whether the students are encouraged to read English literature by our colleagues from specialized departments, see in Fig 1, we asked them: "Do your Pharmacy teachers recommend you to study the professional links, books or materials published in English language?"

$72 \%$ claimed that the teachers recommend them to study English literature.

The result confirms that studying English terminology at FaPhCU is very important and the students really need the terminology knowledge as they need it for English professional texts comprehension. Regarding the teachers' recommendation $\quad 63 \%$ studied English pharmaceutical literature advised by teachers. 37\% did not search for it [13].

The biggest challenge concerning the importance of studying texts in English was induced by the question: "Do you search for the Pharmacy materials in English on your own?”
Regarding 46\% who said "Yes" we can conclude that the students search for and study pharmaceutical literature in English and so they demand new and latest scientific English texts that will help them to study pharmacy at higher level. 54\% do not search for English literature on their own. We would suggest that the literature recommended by their teachers, covers their professional needs [13].

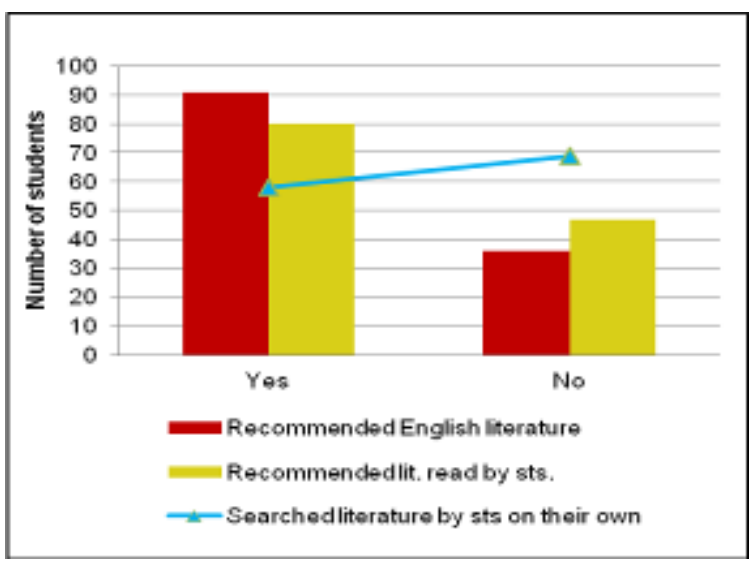

Figure 1. English literature studied by students

To find out whether the Academic English Language Preparation improves students' English professional knowledge, see in Fig 2, firstly we asked: "Did you read English pharmaceutical before attending AELP courses?” to compare the results with the answers to the question "Do you read English pharmaceutical texts after attending AELP courses?” 64\% students did not read professional literature before attending AELP course. 36\% read and studied the professional literature even before attending AELP course. We were satisfied to find out, that $76 \%$ students claimed they started to study English professional literature after attending AELP course. $24 \%$ do not refer to English literature. These students belong to the group of $37 \%$ students who do not search for the teachers' recommended English literature. We suppose that their study is much more complicated as most of the pharmaceutical literature and researches are processed abroad and written in English.

We were also keen on knowing whether after four semester long course our students consider AELP terminology sufficient to understand English pharmaceutical texts. In $90 \%$ they reflected their satisfaction with the terminology embraced in the courses and so they understand English pharmaceutical texts better after attending AELP course. This high percentage of students that are satisfied with the course terminology will also use it professionally in their future carrier. 86\% answered that they will use English pharmaceutical terminology they had to study in AELP courses professionally. 


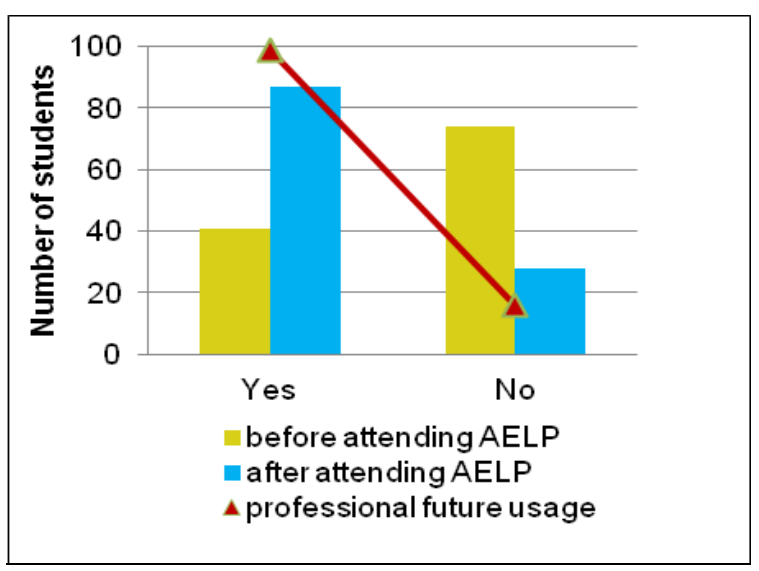

Figure 2. Pharmaceuical texts study

Improvement of our communication and relationship with other departments at FaPhCU is connected with our research goals to know students' opinion on the English terminology interconnection with other pharmaceutical subjects. 100 students claimed that the subjects and the content are interconnected in more than $50 \%$.

As I mentioned above, we provided the research with students who finished the four semester long course. They had the general and concrete overview about the content and terminology studied in the courses. We asked them to share their suggestions of other terminology and professional themes they would like to study in the seminars. $31 \%$ were satisfied with studied terminology. 20\% would like to talk more about the pharmaceutical and analytical chemistry, $17 \%$ about the diseases and disorders and $15 \%$ would involve practical communication with patient in the pharmacy, $8 \%$ about drugs (metabolism, registration in SR) and $8 \%$ had different or no ideas [13]. We have also come to the conclusion that the creation of new concept of teaching English at FaPhCU should be regarded as important by the fact that communication with the patient in a pharmacy should respect the fundamental principles of bioethics.

Communication between students and teacher creates better atmosphere in a classroom. Each student has the opportunity to discuss his problems and requirements in person.

\section{Discussion}

ESP assesses needs and integrates motivation, subject matter and content for the teaching of relevant skills. The term "specific" in ESP refers to the specific purpose for learning English. The ESP approach enhances the relevance of what the students are learning and enables them to use the English they know to learn even more English, since their interest in their field will motivate them to interact with speakers and texts [14].

We, English teachers, have started to study ESL and concentrated on developing all four language skills: listening, speaking, reading and writing. But whether wanted or not we gradually selected and emphasised skills that our students wanted and needed to develop more than the others.

As most of the materials our pharmacy students have to study are in English, firstly we have to focus on reading skills. And reading skills come hand in hand with the terminology acquiring. Pharmaceutical terminology is very broad and specific and contains terms from various fields of study and targets, e.g. chemistry, biology, toxicology, botany and others. The high demands of terminology mastering are not laid only upon the students but also their teacher.

When I became a part of the team at the Department of Languages I did not only meet one of the best professionals and co-workers but step by step I have also been realizing how much work and study I have to accomplish. It is said, that students have to be risk-takers if they want to succeed in English. In ESP teachers case risk-taking takes on totally different meaning. The constant learning and studying of pharmaceutical terminology and professional information is never ending process. Being a resource of pharmaceutical terminology that helps students to identify their language learning problems and to find solutions to them we determine what and how to learn. We take risks and responsibility for making choices of the best way to reach the ESP pharmaceutical goal.

As our pharmacists will work in the pharmacies or in the scientific field, they have to develop their speaking skills. So secondly we focus on effective speaking skills development. Their communication skills will create the atmosphere in the pharmacy. We focus on speaking with understanding and direct our students to express themselves with minimum stress and hesitation. Listening and writing skills are included in teaching to support students' terminology acquiring.

\section{Conclusion}

Academic English Language Preparation seminars help students to master English pharmaceutical terminology, enable them to sustain their professional development and think, write and communicate in the professional language.

Professional pharmaceutical terminology is very broad and comprehensive. It includes terms from many disciplines - pharmacology, toxicology, organic and inorganic chemistry, botany, physics and many others. English teachers, therefore must take into account, while curriculum developing, the programs of individual vocational subjects. Professional seminars in English language do not 
overtake the topics of individual scientific disciplines at FaPhCU. We use materials from popular-scientific literature containing professional terminology.

In conclusion we can say that the inclusion of bioethical issues into pharmaceutical studies and profession remains on the agenda of pharmaceutical professional bodies. It should be emphasized that important research contribution is the introduction of bioethical issues according to the Code of Conduct into the new concept of English language FaPhCU. We rely and take our students' needs and opinions into account and incorporate them into our plans and goals. The sustainability of newly created and validated concepts of English language for pharmacists at $\mathrm{FaPhCU}$ will be compatible with the standards of English language teaching at faculties of pharmacy in non-English speaking countries (e.g. the Czech Republic, Poland, Hungary, Sweden, Denmark, Spain).

The aim of the academic language preparation at FaPhCU is that students master pharmaceutical terminology and understand the principles of bioethics in the pharmaceutical profession. Respecting the Code of Conduct, our pharmacists will be competent to promote ethical principles, dignity, rights and opinions of others and take responsibility for their knowledge and skills.

Finally, only the open and straight dialogue between teachers and students can bring desired results. And we, teachers at $\mathrm{FaPhCU}$, communicate with our students at high and conducive level. The fact is that the longer we communicate with our students, the better picture of their personality and knowledge we acquire.

\section{References}

[1] Institute of Medicine of National Academies, "Evidence Communication Innovation Collaborative", Effective communication about effective care. www.iom.edu

[2] World Health Organization, "Developing Pharmacy Practice. A focus on patient care.”, International Pharmaceutical Federation, Geneva, Department of Medicines Policy and Standards, 2006

[3] Merino I.G., "Native English speaking teachers versus non-native english speaking teachers", Revista Alicantina de Estudios Ingleses 10, University of Nothern Iowa, 2013, pp. 69-79

[4] Kachru B. Braj., "The Other Tongue: English Across Cultures", In Language Problems and Language Planning, University of Illinois Press, Illinois, 1984, pp. 199-212

[5] Your dictionary, "Medical Vocabulary for ESL", http://esl.yourdictionary.com/lesson-plans/medical-vocabu lary-for-esl.html
[6] Žufková V., Kližanová D., Vivoda M., “The importance of new concept of English language teaching at Faculty of Pharmacy depending on compatibility with trends in other countries", International Scientific Publications, Educational Alternatives, Volume 12. pp. 357-365

[7] Takáčová M., "Špecifiká odborného jazyka, odborný preklad a počítačová lingvistika", Odborná komunikácia $v$ zjednotenej Európe II. Univerzita Mateja Bela v Banskej Bystrici, Fakulta humanitných vied, Jednota tlmočníkov a prekladatel'ov, Praha, 2004, pp. 106-111

[8] Ďuricová A., "Je každá komunikácia odborná?", Odborná komunikácia v zjednotenej Európe II. Univerzita Mateja Bela v Banskej Bystrici, Fakulta humanitných vied, Jednota tlmočníkov a prekladatel'ov, Praha, 2004, pp. 2629

[9] General Pharmaceutical Council, "Code of Conduct for pharmacy students”, The British Pharmaceutical Student's Association, London, 2010

[10] Royal Pharmaceutical Society of Great Britain, "Code of Ethics for pharmacists and pharmacy technicians", London, 2007

[11] Ethics Committee, "Code of Ethics of the Pharmaceutical Industry in Slovakia”, SAFS, Bratislava, 2012

[12] Jurečková A., "Výučba cudzích jazykov na vysokých školách a vstup do EÚ”, Odborná komunikácia $v$ zjednotenej Európe II. Univerzita Mateja Bela v Banskej Bystrici, Fakulta humanitných vied, Jednota tlmočníkov a prekladatel'ov, Praha, 2004, pp. 58-59

[13] Žufková V., Kližanová D., Kyselovič J., “Students’ Opinion on Pharmacy Study", In: Ireland International Conference on Education proceedings, Ireland, 2015, pp. 384-387

[14] Fiorito L., “Teaching English for Specific Purposes (ESP)", UE UsingEnglish.com.http://www.using englis h.com/articles/teaching-english-for-specific-purposesesp.html 


\section{Appendix 1: $1^{\text {st }}$ semester Master Study}

Source: healthguru.com
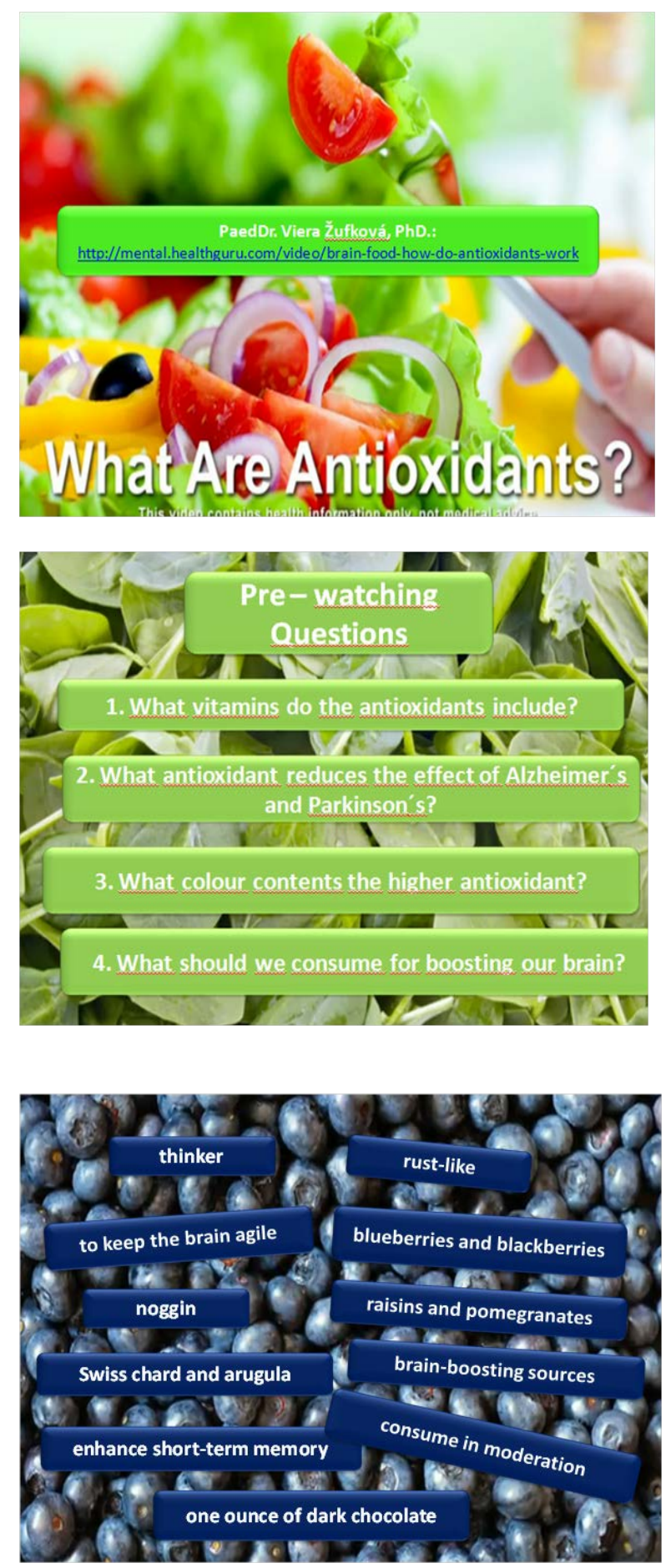
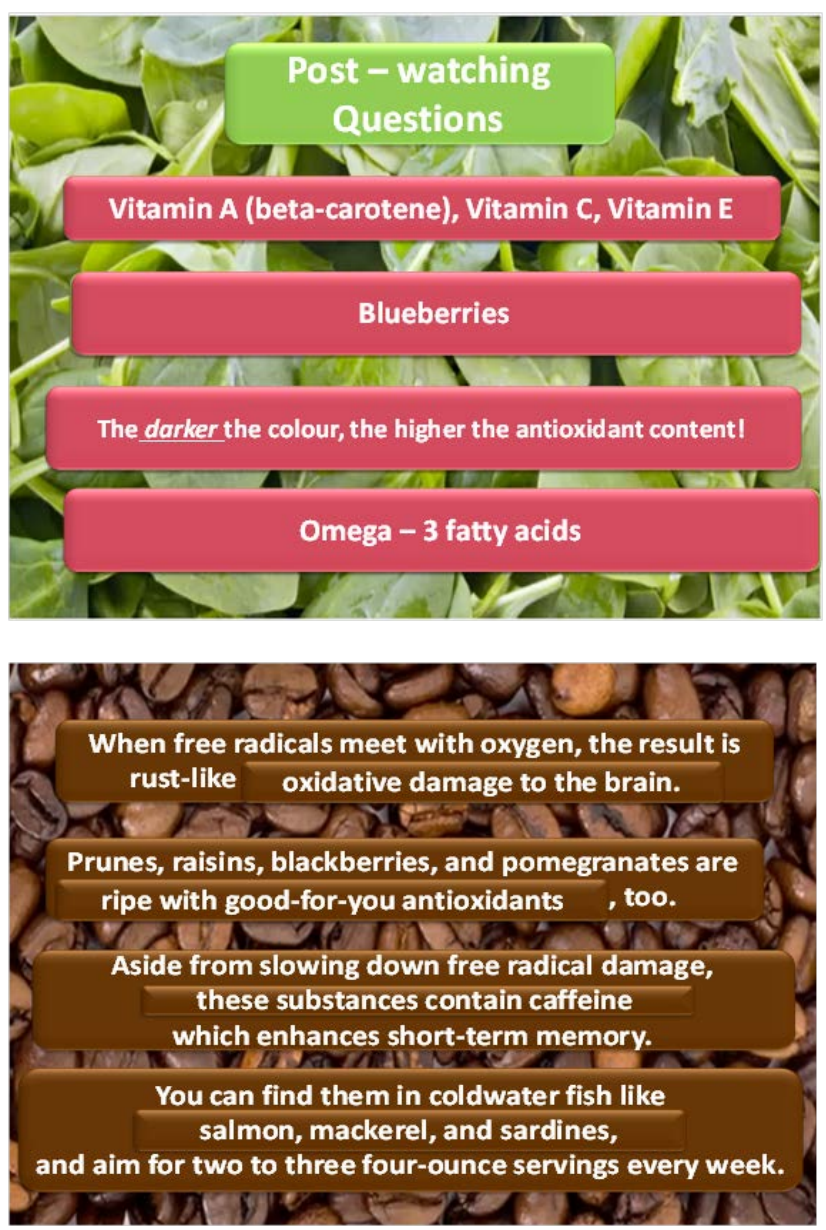

$4^{\text {th }}$ semester Master Study

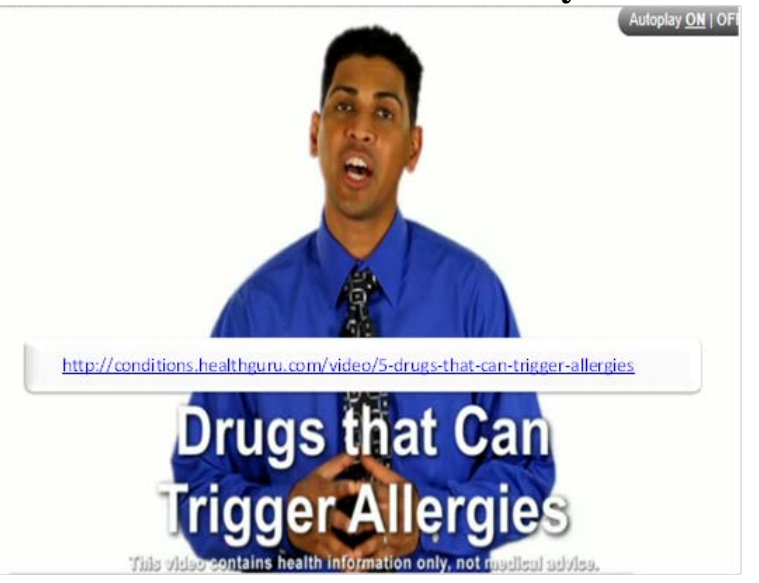



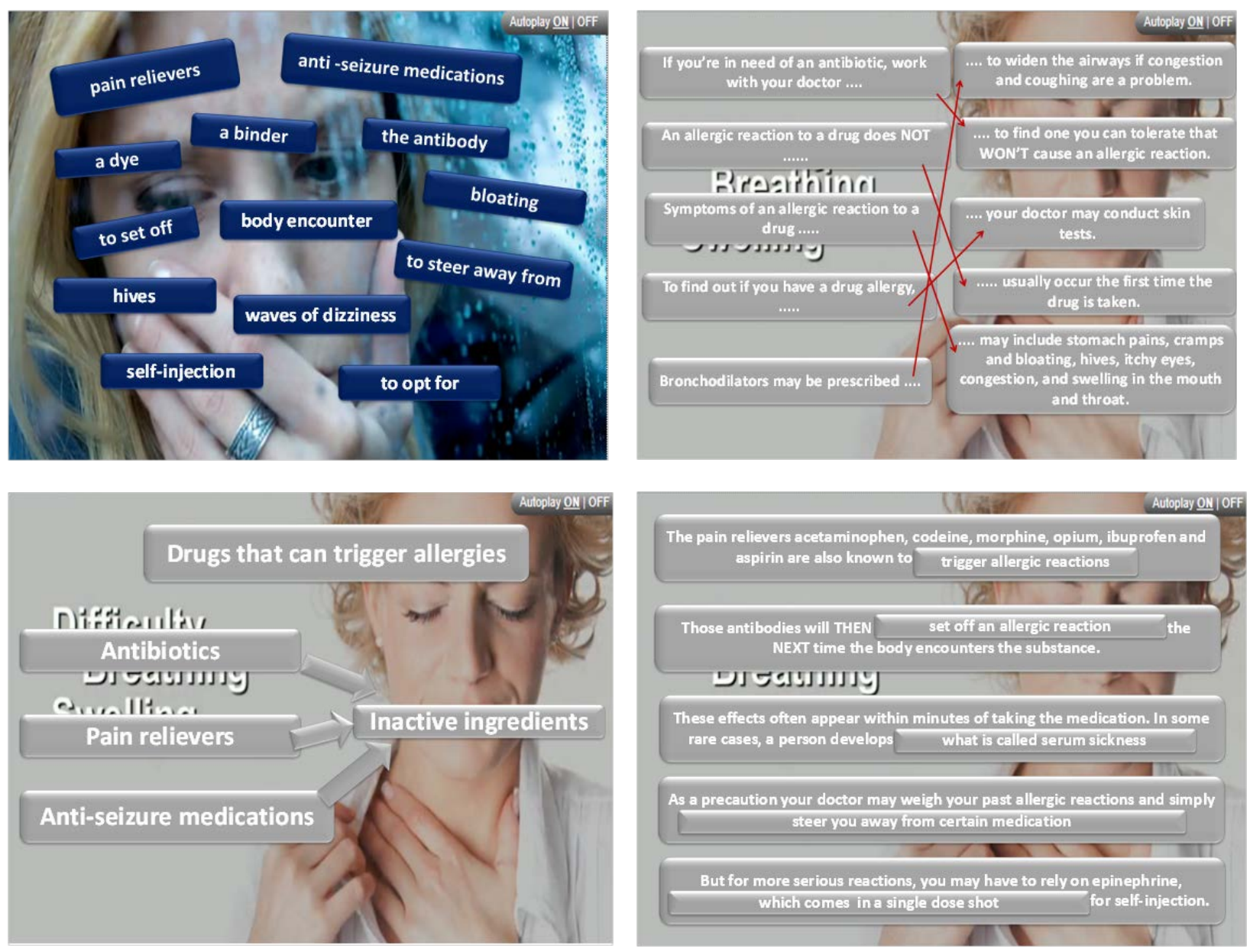